\title{
Language and Politics in Ireland - a Constructive or Destructive Interconnection?
}

Ian James Parsley

\section{(2) OpenEdition \\ Journals}

Electronic version

URL: http://journals.openedition.org/etudesirlandaises/3585

DOI: 10.4000/etudesirlandaises.3585

ISSN: 2259-8863

\section{Publisher}

Presses universitaires de Rennes

\section{Printed version}

Date of publication: 20 December 2013

Number of pages: 151-159

ISBN: 978-2-7535-2887-1

ISSN: 0183-973X

\section{Electronic reference}

Ian James Parsley, « Language and Politics in Ireland - a Constructive or Destructive

Interconnection? », Études irlandaises [Online], 38-2 | 2013, Online since 20 December 2015, connection on 06 May 2019. URL : http://journals.openedition.org/etudesirlandaises/3585; DOI : 10.4000/ etudesirlandaises.3585

This text was automatically generated on 6 May 2019.

(c) Presses universitaires de Rennes 


\title{
Language and Politics in Ireland - a Constructive or Destructive Interconnection?
}

\author{
Ian James Parsley
}

One of the biggest challenges faced by minority language movements across Europe is the association that most people inherently make between a language and a people, or a nation. After all, if most people who speak Slovene are Slovene, and most people who are Slovene speak Slovene, then why would the same correlation not apply to any other language? As a result, almost inevitably and often unintentionally, minority language development becomes associated with movements of national determination, of whatever kind - summed up perhaps by the old Welsh maxim Cenedl heb iaith, cenedl heb galon ("a nation without a language is a nation without a heart"). The difficulty is that the correlation is almost universally inaccurate. This paper argues that the correlation between "language" and "nation" is often unhelpful to minority language development, particularly with reference to Ulster Scots (defined as the variety of the Scots tongue spoken in parts of Northern Ireland and County Donegal), and that indeed the "language versus dialect" debate this correlation inevitably engenders is pointless and unhelpful.

2 How is the correlation between "language" and "nation" inaccurate? Most obviously, most people who speak English (however defined) are not English; indeed, counting those who speak it fluently as a second language, England itself is a comparatively minor part of the modern English-speaking world. Furthermore, the recent census of England and Wales demonstrated clearly that an increasing minority of English and Welsh residents (8\%) do not in fact speak English at home (or at all) ${ }^{1}$. The correlation therefore falls down immediately in the case of the world's most widely spoken language.

Even within the boundaries of Europe, where the "nation state" (which is often defined or was defined by linguistic boundaries) took root, the correlation is of scant value. Most French people do indeed speak French - but so do lots of Belgians and Swiss. Proportionately as many Austrians speak German as Germans; yet Austria was itself once the centre of a multi-national and multi-lingual empire which, even after the 
"independence" of many of its nation states, has left linguistic minorities all over the place. A third of Hungarian speakers in Europe do not live in Hungary - many live in Romania; yet many Romanian speakers live in Moldova. Polish is indeed the dominant language in Poland, but is also now the second language of the UK and Ireland - the 17,700 Northern Ireland residents declaring it as their "main language" at the 2011 census outnumber those for Irish by four to one. Some Italians speak German; some Czechs speak Slovak; some Estonians speak Russian. This is before we get into the "language definition" debate - some Spaniards speak Galician (perhaps closer to Portuguese than Spanish); some Swiss speak "Swiss German"; most Luxembourgers switch between Germanic Luxembourgish and Standard French depending on context. Even though international frontiers came sometimes even to mark linguistic frontiers (e.g. between German and Dutch), even a Europe of over 50 sovereign units does not match "nation" with "language" in any meaningful way.

(n) scrutiny in the case of widely known national and administrative languages, why then do we insist on assuming the two are linked when it comes to minority languages? It is widely assumed that anyone who takes an interest in the development of, for example, Catalan or Scots is likely to be a Catalan or Scottish Nationalist; indeed, most people would assume the two are directly interlinked, with the language used (or abused, according to preference) to emphasise the distinct "national identity" of the would-be independent state. It is not for me to determine whether or not this helps the political objective being assumed; but I am certain it hinders the linguistic one.

5 The fact, with both the above examples, is that Catalan and Scots are widely spoken languages in certain spheres of life (exactly which spheres differ, with Catalan now enjoying much wider access to more formal, educational and administrative settings than Scots does). The fact is also that their speakers are almost all proficient in the dominant administrative language of the state (Spanish in the case of Catalonia/Spain and English in the case of Scotland/UK), and that this "dominant" language also has a wider global role, and thus international economic and diplomatic importance, as one of the most widely spoken languages on the planet. Therefore, to tie the minority language in with an independence movement is to suggest the minority language could one day enjoy the same status as the currently "dominant" language - even though Spanish and English have obviously global reach and Catalan and Scots obviously never will. However, this is plainly a ludicrous suggestion. The current national governments of Catalonia and Scotland may aspire to independence on a par with the rest of Spain or the UK, and they have every right to that aspiration, but most of their residents - even those pre-disposed to support the objective of independence - would recognise that suggesting minority languages could or even should ever enjoy parity in a globalised world with languages such as Spanish or English is quite ridiculous (and conceivably even economically harmful if they are taught in preference to the core science and technology subjects which many people feel will drive the $21^{\text {st }}$ century economy). The result is that tying minority languages to independence movements suggests an unattainable objective for those minority languages - leading a lot of people, even those instinctively supportive of the independence movements, to give up on them altogether.

6 Across the "Sheuch" from Scotland lies Northern Ireland, which naturally has its own constitutional peculiarities. Here, the "Irish" language had already become intertwined in the familiar way with Irish Nationalism, itself assumed to correlate with Irish Catholicism 
too. Thus, Scots (known in Northern Ireland and the border counties of Ireland as "Ulster Scots", in the same way Dutch in Belgium is often referred to as "Flemish") became intertwined with Unionism. Given the tendency for minority languages to be associated with breakaway national movements, it in fact became more obviously associated with "Loyalism", a form of Unionism which vehemently opposes any hint of unity with the rest of Ireland and yet regards its affiliation to Britain as strictly conditional, to such an extent indeed that minority strands of "Loyalism" have even hinted at a last-ditch preference for a separate Protestant State in the north east of Ireland, as was evidenced notably through the "Ulster Clubs" movement in the 1990s, for example. However, the link between the Scots tongue as spoken in Ireland (Ulster Scots) and "Loyalism" bears no relation to reality whatsoever. This is immediately obvious from the fact that contemporary Ulster Scots is spoken exclusively in rural areas and "Loyalism" is more evident in the urban inner-city.

Government departments and agencies in Northern Ireland have, unfortunately, subscribed to the fiction that "Ulster Scots" and "Loyalism" are somehow linked. As recently in 2012, a Department of Culture consultation running from July to November 2012 referred throughout, including in its title, to "Ulster-Scots language, heritage and culture", in such a way as to suggest in effect that the Scots language and Loyalist heritage and culture were to be regarded as a single unit, when in reality they are almost entirely distinct, even geographically. As a result, the language has come to be almost totally ignored; since it is tied to a group of people who do not speak it, any attempts at promoting it inviting ridicule, with the result that most people in Northern Ireland refuse to believe that there are any speakers. Ulster Scots speakers themselves, meanwhile, are left marginalised from any attempts at "promotion", because almost all such attempts are aimed, for "culture and heritage" reasons, at a completely different set of people - people who actually speak English! This is a perfect example of the risk of trying to link "language" to "nation" - sometimes the two scarcely coincide at all.

8 Another difficulty for Ulster Scots, given its implicit association with "Loyalism" and thus with "Unionism" (and therefore against Nationalism), is that its proponents have often been unwilling to share their development work with those developing Scots in Scotland, precisely because the latter are assumed (often correctly) to be in favour of Scottish independence and thus of a completely opposing view concerning the constitutional future of the UK. As a result, the tendency in Northern Ireland has been to argue for language status for "Ulster Scots" alone, suggesting it is distinct not just from "English" but also from "Scots". Politically this is bizarre and linguistically it lacks any justification whatsoever. Politically, it amounts to supposed Unionists (i.e. people assumed to support linkage between Northern Ireland and Great Britain) opposing an obvious link to Scotland; linguistically, there simply is no case for suggesting Ulster Scots in distinct grammatically, lexically or phonologically from Scottish Scots, and indeed its development in harmed by doing so. Denying - for political reasons - the obvious linguistic links between Ulster Scots and Scottish Scots deprives Ulster Scots of much of its interest; why would proponents of any variety of Scots wish to cut themselves off linguistically from the writings of Burns (including "Auld Lang Syne" and "Burns Nights") or the vocabulary of the game of golf (putt, links, divot, etc.), when these are the key introductory points of immediate and obvious interest to millions of people even well beyond the British Isles? 
The other fundamental difficulty with the false intertwining of "nation" and "language" in the case of minority languages is that too many proponents of minority languages are inclined to take an attack on one as an attack on the other, and define them in similar terms. For example, a suggestion that Scots is not a "language" in the true sense is not, in fact, an attack on the idea that the Scottish nation could do perfectly well as an independent country; it is merely a suggestion that the Scots language is not used across the whole range of settings from formal to informal. People who are inclined to tie together minority language development with campaigns for political independence are inclined to spend a lot of time arguing over language status in the same way they argue over national status, despite the fact that the two are entirely separate arguments! Scots could quite easily be revived with Scotland remaining in the UK. After all, Welsh has flourished within the UK far more than Irish has in the independent Republic of Ireland; on the other hand, an independent Scotland could quite easily decide to promote English for economic reasons to the exclusion of Scots.

This point transfers to Northern Ireland too. The suggestion that Ulster Scots is not a language, or at least lacks the range that English has, is often taken as an insult to Loyalist or broader Unionist culture because that culture is supposedly intertwined with the Ulster Scots language. It is noteworthy that the public figures who react most vehemently to this suggestion are, without exception, unwilling to utter so much as a word in Ulster Scots - because, as established above, they actually speak English! Visiting actual speakers of Ulster Scots, on the other hand, one is instantly struck how unconcerned they are about the "language versus dialect" debate (in much the same way speakers of Swiss German are unconcerned about it). The most prominent living poet in Ulster Scots, Jim Fenton, has long studiously avoided the debate altogether by referring to it as a "tongue" - precisely because he wants people to enjoy it, not argue about it!

Why is this? Here, I proceed with caution because when assessing a group of people, however defined, it is easy to drift into generalisation and conjecture. Nevertheless, much of this still derives, in my view, from the "Siege Mentality" of many Ulster Protestants, a mentality which is felt very much to be literal.

The story of "The Siege", which in Northern Ireland needs no further definition to be taken automatically to mean the 1689 Siege of Derry, is highly relevant here. The albeit slightly simplified narrative carried down to the present day involves not just the clash between the Catholic "Irish" Jacobites seeking to take the city and the mainly Presbyterian "Ulster Scots" city residents who held out against all odds, but also the "English" - namely the English ships which waited in Lough Swilly for months instead of intervening, and (in common Ulster Protestant perception at least) leaving those inside the city walls to starve. This presentation of the "English" as essentially gutless and untrustworthy remains characteristic of much Ulster Protestant mentality and instinct to this day. Ironically this further enforces the "siege mentality" of the community as they see themselves caught between an adversary on one side (the "Irish") and fellow countrymen they don't trust on the other (the "English").

It is this which, long pre-dating any "language" movement, gives the notion of "Ulster Scots" - even if it was not always so widely referred to as such - a particular resonance for many Ulster Protestants, particularly those for whom "identity" is most important. The world over, those who are most preoccupied with identity generally tend to be those of more limited means, i.e., these days, those in the inner cities and some rural locations. Exactly how this played out politically and linguistically has varied from time to time. 
Most "Ulster Scots" instinctively took the American side in 1776, many joined the 1798 rebellion, some (including nearly a third of Presbyterian Ministers in Ulster as noted in a recent BBC documentary series on Irish Presbyterianism) were supportive of Home Rule at least until the $\mathrm{Ne}$ Temere decree of $1907^{3}$. Prior to the Victorian Age, Ulster Scots were marked for the priority they gave to education and particularly literacy, but in creative writing and particularly in poetry many purposefully followed Scots norms - including not just vocabulary, spelling and grammar but even verse forms - rather than English ones; i.e. they preferred Burns to Wordsworth. The County Down poet, Hugh Porter, writing at the start of the $19^{\text {th }}$ century, perhaps summed it up best when he wrote of his own use of language (and, perhaps, of his own identity):

$[. .$.$] in the style appears,$

The accent o' my early years,

Which is nor Scotch nor English either,

But part o' baith mix'd up thegither:

But it's the sort my neighbours use,

Wha think shoon prettier far than shoes ${ }^{4}$.

Perhaps his more famous contemporary, James Orr from Ballycarry in County Antrim, went further and dismissed the English entirely, most notably in "Ode to the Potatoe 5 " where he mocks the "English" for requiring so many crops when the "Irish" (to which he is clear he belongs, if only by virtue of his birth and upbringing on the island of Ireland) make do perfectly well with one - a poem made, in retrospect, almost into a tragedy by the Great Famine little more than a generation later.

In other words, politically and linguistically, the notion of "Ulster Scots" has long been compelling for Ulster Protestants, as has the link between the politics and linguistics of "Ulster Scots", based as they are upon Ulster Protestants' sense of being trapped (indeed, besieged) between the English and the Irish; however, how precisely this has revealed itself has swung dramatically over time. Those who define themselves as "Ulster Scots" have always been split fully three ways, Nationalist, Liberal and Unionist, but exactly in which proportion has varied hugely from generation to generation, and may do so again.

So it is that we arrive at a contemporary situation in which most (though not all) who associate themselves with "Ulster Scots" regard themselves as "Unionist", seeing the two as intertwined, and yet often at the same time rejecting outright any direct linguistic association between "Ulster Scots" and "Scots"; in other words, for many, Ulster Scots has become something to be associated exclusively with "Ulster" and not shared with Scotland. It is a peculiar thing, surely, for "Unionists" who support the link with Great Britain politically to deny it linguistically?

Yet the combination of the two core parts of this paper explains this peculiarity, at least in part. Firstly, because everything in Northern Ireland is mirrored into two sides: if "Nationalists" have their own exclusive culture (incorporating a language), so must "Unionists" have theirs. Secondly, as we have seen with regard to the Loyalists, most "Unionists" belong to a heritage which, while supportive of the link with Great Britain, is also greatly suspicious of the people who live there. These combine to explain why "Unionists", having in fact secured their constitutional future as best they possibly can within the UK, remain so wary and suspicious. This lack of confidence cannot easily be overcome.

It was noted earlier also that many Ulster Scots, at least historically, had in fact been "Liberals" (now most likely to associate with the contemporary Alliance Party rather than 
any of the Unionist groupings). Historian Eamon Phoenix notes that, even in the run-up to the Covenant of 1912 led by all the great Unionist Leaders of the time designed to demonstrate their determination to remain fully part of the United Kingdom, entire hamlets in Scots-speaking and predominantly Protestant parts of rural Ulster (such as Armoy) refused to sign ${ }^{6}$. This provides evidence of the presence, even at that stage, of a radical Liberal tradition running contrary to the perceived Conservatism of "Unionists". It is even conceivable that it suggests that certain "Ulster Scots" did not necessarily regard themselves as "British" in preference to "Irish".

So what do modern "Liberals" make of this intertwining of language and culture? In truth, they do not think much about it. Liberals across the world tend to focus more on the reasoned and rational, and thus make political appeals to the "head", where many others focus more on the emotional and indeed identity-based, thus making political appeals to the "heart". The recent Flags Dispute over Christmas 2012 was a classic example: the Liberals took a rational position that the flag on Belfast City Hall should change from flying 365 days a year as it always had in Belfast to flying on "designated days" as was the case with most Councils in the rest of the UK, in a way which would maintain the flying of the sovereign flag without overdoing its use in the centre of a city of divided national affiliations. Unionists, particularly Loyalists, took the more emotional position that "their flag" was being "taken away". The fact that once-militant Irish Republicans, for the first time in the history of Ireland, voted to fly the Union Flag over a civic building was lost to all sides, even though in theory it was a thorough endorsement of both the Liberal position (on the flag) and the Unionist position (on the constitution). Liberals were unable to engage at the emotional, identity-based level in order to claim victory; and for aforementioned reasons, Unionists are always too suspicious to engage rationally to claim it.

Similarly, on language, Liberals tend to focus merely on the use of language as a mode of direct communication, rather than on the intertwining of language and political identity (and the way in which language can be used to communicate much more than just what is conveyed by the words themselves). In the same way they dismiss emotional attachments to symbols, they dismiss emotional attachments to languages. Although in theory Alliance Party policy in recent manifestos is supportive of the development of all minority languages, this support rejects any notion that "indigenous" languages such as Irish and Ulster Scots should be treated any differently from more recently arrived languages such as Cantonese and Polish, and in practice gives such primacy to English that other languages would perhaps be best subtly forgotten. Indeed, Alliance election leaflets have appeared with small sections in Polish, Chinese and Lithuanian but never in Irish or Ulster Scots. This is, rationally, an entirely sensible policy position and party strategy, of course. However, does it do justice to the emotional side, based as it is on centuries of the intertwining of language, politics and identity?

\section{Conclusion}

The whole thing has, in my view, broader political implications for Northern Ireland. Once one accepts that "language" and "nation" are not necessarily intertwined, and may indeed not be connected at all, one can begin to imagine that the whole diametric view of Northern Ireland to which we are supposed to subscribe may not be true at all. Under nationality, we are supposed to choose "Irish" or "British"; under political affiliation 
"Nationalist" or "Unionist"; under religious background "Catholic" or "Protestant"; under language "Irish Gaelic" or "Ulster Scots"; under sporting preference "GAA" or "hockey/cricket"; even under football team "Celtic" or "Rangers". However, if the correlation between "language" and "nation" does not stand up to scrutiny, do any of these other correlations?

Once we in Northern Ireland begin to accept that the idea that to be "German" you have to speak "German" and to speak "German" you have to be "German" is a myth, suddenly a whole lot of other myths become apparent - such as the one that we must neatly box ourselves into compartments marked "Irish-Nationalist-Gaelic" or "British-UnionistUlster Scots". Once we recognise that in fact we may wish to exercise a free choice in distinguishing between "language" on one hand and "nation" (or "culture and heritage") on the other, a very different, new Northern Ireland opens up - one which is not so much bitterly divided as fascinatingly multi-faceted. Is a future embracing that new Northern Ireland not much, much better than the one in which a bitter sectarian conflict has cost thousands of lives?

\section{NOTES}

1. See: http://www.ons.gov.uk/ons/rel/census/2011-census/detailed-characteristics-ondemography-for-2011-census-merged-wards-and-middle-layer-super-output-areas-inengland-and-wales/info---english-language-proficiency-in-england-and-wales.html

2. "Sheuch", meaning "a narrow, open drain or ditch" (James Fenton, The Hamely Tongue, The Ullans Press, 1995) is also used to refer to the North Channel, between Scotland and the north-east of Ireland.

3. See "Taking Root", BBC Northern Ireland documentary by William Crawley, March 2013, one of the three-part An Independent People series: http://www.bbc.co.uk/ programmes/b01qt8s3

4. Hugh Porter, "The Author's Dedication to the Right Hon. Earl of Moira. The Author's Preface", Amber Adams \& J.R.R. Adams (ed.), The Country Rhymes of Hugh Porter. The Bard of Moneyslane, Bangor, Pretani Press, 1992, p. XXIX.

5. Philip Robinson (ed.), The Country Rhymes of James Orr. The Bard of Ballycarry, Bangor, Pretani Press, 1992, p. 1-4.

6. See "The Ulster Covenant" documentary, by William Crawley (http://www.bbc.co.uk/ programmes/b01mzlgw) shown on BBC Northern Ireland in September 2012. 


\section{ABSTRACTS}

This paper demonstrates that the idea that a language, a culture and a nation are tied together as one single unit just because they share the same name is almost always fundamentally flawed. In Northern Ireland, the tying together of "Irish language", "Irish culture" and "Irish Nationalism" has led to a mirrored response from opponents of Irish Nationalism, who have sought to present "Ulster Scots language, heritage and culture" as a single entity. Because they are not a single entity, the outcome of this has been the presentation of "Ulster Scots" as something at best unreal and at worst invented. This has merely meant that the identity crisis that some in Northern Ireland are experiencing has continued, while much needed work on promoting "Ulster Scots language" and "Ulster Scots culture" as the distinct entities they are has gone undone.

Cet article démontre que l'idée qu'une langue, une culture et une nation puissent former une seule entité simplement parce qu'elles partagent le même nom est presque toujours fondamentalement erronée. En Irlande du Nord la façon dont la « langue irlandaise », la « culture irlandaise » et le «nationalisme irlandais » ont été reliés ensemble a produit un effet de miroir parmi les opposants au nationalisme irlandais, qui ont tenté de faire croire que «la langue, l'héritage et la culture Ulster Scots » constituent un seul et même bloc. Or, puisque ces éléments ne constituent pas un seul bloc, le résultat de cette stratégie a été que l'« Ulster-Scots » paraît au mieux, irréel, au pire, inventé. Ainsi, la crise identitaire que vivent certains en Irlande du Nord n'a pas été résolue, et beaucoup de travail qui aurait dû être fait pour promouvoir la «langue Ulster Scots » et la « culture Ulster Scots » n'a pas été effectué.

\section{INDEX}

Keywords: collective identity, cultural heritage, Irish nationalism, languages in Ireland language policy, languages in Ireland - Ulster-Scots, Northern Ireland, Ulster-Scots

Mots-clés: héritage culturel, identité collective, Irlande du Nord, langues en Irlande - politiques linguistiques, langues en Irlande - Ulster-Scots, nationalisme irlandais, Ulster-Scots

\section{AUTHOR}

\section{IAN JAMES PARSLEY}

Chairman of the Ulster-Scots Broadcast Fund 